\title{
PEMIKIRAN FAZLUR RAHMAN (PRAGMATIS- INSTRUMENTAL) TENTANG PENDIDIKAN DAN RELEVANSINYA DENGAN DUNIA MODERN
}

\author{
Luthfi Hibatullah \& Ahmad Qomarudin \\ Universitas Islam Negeri Sunan Kalijaga \\ 19204020038@student.uin-suka.ac.id, ahmadqomarudin707@gmail.com
}

\begin{abstract}
In the world of education the dichotomy between religion and general science is no longer a new problem in the Islamic education system. This discourse bas emerged for a long time and is still a complex issue that has not been resolved. This is due to the boundary between religious and non-religious studies taught in each educational unit. From this, Fazlur Rahman proposed the idea of reforming all Islamic education systems. What is gained from experience, making observations and various research. So this research focuses on the intellectual biography of Fazlur Rahman, Fazlur Rahman's educational thoughts and educational thoughts in Indonesia, and the relevance of the two. In this study the authors used data collection methods with documentation methods, which are in data collection techniques in library research (library research).
\end{abstract}

Keywords: Thought, Education, Fazlur Rabman

\begin{abstract}
Abstrak : Dalam dunia pendidikan dikotomi antara ilmu agama dan ilmu pengetahuan umum bukan lagi menjadi permasalahan yang baru dalam sistem Pendidikan Islam. Wacana tersebut telah lama muncul dan masih menjadi persoalan rumit yang belum terselesaikan. Hal ini disebabkan karena batasan antara kajian yang bersifat agama dan non-agama yang diajarkan pada setiap satuan pendidikan. Dari sinilah Fazlur Rahman mengajukan gagasan mengenai pembaharuan terhadap semua sistem pendidikan Islam. Yang didapat dari pengalaman, melakukan pengamatan dan berbaga peneltian. Maka penelitian ini berfokus pada biografi intelektual Fazlur Rahman, pemikiran pendidikan Fazlur Rahman dan pemikiran pendidikan di Indonesia, dan relevansi antara keduanya. Dalam penelitian ini penulis menggunakan metode pengumpulan data dengan metode dokumentasi, yang ada dalam teknik pengumpulan data pada penelitian kepustakaan (library research).
\end{abstract}

Kata Kunci: Pemikiran, Pendidikan, Fazlur Rahman

As-Sabiqun : Jurnal Pendidikan Islam Anak Usia Dini

Volume 3, Nomor 1, Maret 2021; 26-44

https:/ / journal.stitpn.ac.id/index.php/assabiqun 


\section{PENDAHULUAN}

Kemajuan ilmu pengetahuan dan teknologi bisa dirasakan begitu pesat. Namun, tidak dapat dipungkiri bahwa kemajuan yang begitu signifikan bukan atas prakarsa umat muslim, melainkan dipelopori oleh orang-orang Barat. Hal inilah yang menjadi salah satu faktor yang mendorong Fazlur Rahman ikut memberikan sumbangsih bagi Islam maupun bagi dunia, baik berupa tenaga, kritikan, karya ilmiah dan lain sebagainya.

Namun, banyak pembaharuan yang terjadi di Timur Tengah seperti Jamaluddin al-Afghani (1839-1897 M), Muhammad Abduh di Mesir (1845-1905M), Sayyid Ahmad Khan di India (1817-1898M), dan Rasyid Ridha (1865-1935M). Dari sini nampak bahwa umat Islam mulai bangkit dari keterpurukannya. Memahami betapa pentingnya membuka kembali pandangan umat Islam terhadap pengetahuan.

Fazlur Rahman termasuk salah satu pembaharu dalam hal pemikir peradaban Islam, ia juga seorang filusuf, pemikir pendidikan, dan juga ahli tafsir. Hal ini dikarenakan didikan dari sang ayah sejak Fazlur Rahman kecil. Kehidupan Fazlur Rahman juga dilatar belakangi dengan suasana kebangkitan kembali pengetahuan dengan berbagai permasalahannya pasca gerakan pembaharuan yang terjadi di Timur Tengah.

Pendidikan Fazlur Rahman diawali dengan bersekolah di negaranya, yaitu di India kemudia dilanjutan dengan sekolah modern. Namun, Fazlur Rahman memutuskan untuk berangkat ke Inggris, didasarkan atas ketidakpuasan terhadap rendahnya mutu pendidikan Islam yang ada di India. Menurut Fajlur Rahman studistudi Islam yang ada di daerahnya kurang kritis dibandingkan studi-studi Islam yang dikembangkan di Barat.

Selama perjalanannya menjalani kehidupan di Barat, Fazlur Rahman berpendapat bahwa tidak seharusnya terjadi pemisahan antara ilmu agama dan ilmu pengetahuan. Karena antara kedua memiliki keterkaitan antara satu dengan yang lainnya. Dari sinilah banyak gagasan yang diutarakan oleh Fazlur Rahman mengenai pendidikan yang didapatkannya melalui pengalaman, pengamatan dan penelitian yang dia lakukan selama ini. 
Dalam penelitian ini penulis menggunakan teknik pengumpulan data mengunakan studi dokumentasi. Studi dokumentasi merupakan teknik pengumpulan data pada penelitian kepustaaan (library research) yang sesuai dengan subjek penelitian. Dokumen yang digunakan dapat berupa catatan pribadi, surat pribadi, buku harian, laporan kerja, atupun buku-buku yang bersinggungan dengan subjek peneltian. ${ }^{1}$

Jenis penelitian ini adalah penelitian pustaka, maka sumbernya berasal dari bukubuku yang membahas mengenai pemikiran pendidikan Fazlur Rahman. Adapun teknik pengumpulan data yang digunakan penulis adalah mengumpulkan sumbersumber primer maupun skunder yang berupa buku yang ada sangkut-pautnya dengan tema pembahasan. Dalam tulisan ini penulis menggunakan analisis diskriptif analitik, yaitu suatu pengambilan kesimpulan terhadap suatu objek, berbagai pemikiran, gambaran secara sistematis, faktual serta hubungannya dengan fenomena yang dianalisis. $^{2}$

\section{METODE PENELITIAN}

Penelitian (Research) merupakan rangkaian kegiatan ilmiah dalam rangka pemecahan suatu masalah, hasil penelitian ini tidak pernah dimaksud sebagai suatu pemecahan (solusi) langsung dari permasalahn yang dihadapi, karena penelitian merupakan bagian saja dari usaha pemecahan masalah yang besar. Fungsi penelitian adalah mencarikan penjelasan dan jawaban terhadap permasalahan serta memberi alternatif bagi kemungkinan yang dapat digunakan untuk pemecahan masalah. ${ }^{3}$ Penelitian ini termasuk dalam penelitian pustaka (library Research), yakni penelitian yang objek kajiannya menggunakan data pustaka sebagai sumber utama yang berasal dari buku-buku pemikiran Fazlur Rhman. ${ }^{4}$ Penelitian ini dilakukan dengan tahapan membaca, menelaah, dan menganalisis berbagai bahan literasi yang ada, berupa buku-buku karya Fazlur rahman, maupun karya lain yang ada kaitanya dengan pemikiran Fazlur Rahman beserta dengan Relevansinya

${ }^{1}$ Sukandrrumidi, Metodologi Penelitian: Petunjuk Praktis untuk Peneliti Pemula, (Yogyakarta: GADJAH MADA UNIVERSITY PRESS, 2012), 100-101.

${ }^{2}$ Maragustam, Filsafatpendidikan Islam MenujuPembentukanKarakter, (Yogyakarta :Pascasarjana UIN SunanKalijaga, 2018), 7.

${ }^{3}$ Saifuddin Anwar. Metode Penelitian, (Pustaka Pelajar Ofset, Yogyakarta, cet III, 2001) 1

${ }^{4}$ Mahmud, Metode Penelitian Pendidikan. CV. Pustaka Setia. Bandung, 2011. 9 


\section{PEMBAHASAN}

\section{Biografi Intelektual Fazlur Rahman}

Fazlur Rahman lahir di daerah Hazara daerah Barat Laut Pakistan pada tanggal 21 September 1919 bertepatan dengan tahun 1338 H. Fazlur Rahman terlahir di tengah keluarga yang taat dalam melaksanakan ibadah. Ayahnya bernama Maulana Sahab al-Din, seorang alim terkenal lulusan Dar al'Ulum, Deoband. Fazlur Rahman mampu menghafal al-Qur'an pada usia 10 tahun berkat didikan dari sang ayah. Disiplin tinggi serta ketekukan belajar agama yang diterapkan oleh sang ayah mampu membentuk Fazlur Rahman menjadi pribadi yang mampu menghadapi berbagai macam peradaban dan tantangan di era modern. Dari ibunya Fazlur Rahman belajar mengenai kejujuran, kasih sayang, serta kecintaan sepenuh hati. ${ }^{5}$

Pada tahun 1933 Fazlur Rahman melanjutkan studinya ke Lahore dan memasuki sekolah modern. Pada tahun 1940 Fazlur Rahman menyelesaikan B.A.-nya dalam bidang bahasa Arab di Universitas Punjab. Pada tahun 1942 Fazlur Rahman telah menyelesaikan Masternya dalam bidang bahasa Arab di Universitas Punjab. Pada tahun 1946 Fajlur Rahman berangkat ke Inggris melanjutkan studinya di Oxford dan menyelesaikan progr Ph.D.-nya pada tahun 1949. ${ }^{6}$

Keputusan Fazlur Rahman untuk melanjutkan studinya di Barat didasarkan atas ketidakpuasan terhadap rendahnya mutu pendidikan Islam yang ada di India. Menurut Fazlur Rahman studi-studi Islam yang ada di daerahnya kurang kritis dibandingkan studi-studi Islam yang dikembangkan di Barat. Hal ini merupakan keputusan besar mengingat pada waktu itu merupakan hal aneh di India apabila seorang Muslim pergi menimba ilmu tentang Islam ke Barat dari pada tetap berada di India. $^{7}$

Dengan gelar akademik yang telah dicapai oleh Fazlur Rahman menunjukkan penguasaan terhadap banyak ilmu dan bebagai bahasa, yang menunjukkan Fazlur Rahman sebagai seorang scholar yang intelektual. Sehingga, Fazlur Rahman memutuskan untuk tinggal di Barat selama beberapa tahun lagi. Akhirnya, ia

\footnotetext{
5 Sutrisno, Fålur Rabman: Kajian Terbadao Metode, Epistimologi, dan Sistem Pendidikan, (Yogyakarta: Pustaka Pelajar,2006), 60-61.

${ }^{6}$ Sutrisno, Fazlur Rahman, 61-62.

7 Taufik Adnan Amal, Islam dan Tantangan Modernitas: Studi atas Pemikiran Hukum Fazlur Rahman, (Bandung: Mizan, 1994), 80-81.
} 
mengajar di Universitas Durham (Inggris), kemudia pindah ke Institute of Islamic Studies (Universitas McGill), dan sebagai Assiciate Proffesor of Philosophi sampai awal tahun 1960. Pada tahun itu pula Fazlur Rahman diminta kembali ke Pakistan oleh Ayub Khan, Presiden Pakistan saat itu, yang diminta partisipasinya dalam pembangunan negara Pakistan. ${ }^{8}$

Perkembangan pemikiran Fazlur Rahman dapat dilihat dari banyak karya yang telah diterbitkan. Perkembangan pemikiran Fajlur Rahman dapat diklasifikasikan kedalam tiga periode beserta karya-karyanya. Berikut adalah klasifikasi perkembangan pemikiran Fajlur Rahman: ${ }^{9}$

1. Periode Pembentukan

Dalam periode pembentukan Fazlur rahman mulai meletakkan dasar-dasar pemikiannya dan mulai berkarya. Periode ini dimulai ketika Fazlur Rahman mulai belajar hingga pulang ke negerinya. Pemikiran dan karya Fazlur Rahman didominasi oleh pendekatan historis. Yaitu, melihat Islam bukan dari sisi alQur'an dan as-Sunnah secara ansich, melainkan Islam menjadi realitas dalam kehidupan. Berikut karya-karya Fajlur Rahman dalam periode pembentukan:
a. Avecinna's Psychology.
b. Avecinna,s De Anima, being the Psychologycal Part of Kitab al-Sfiha'.
c. Prophecy in Islam: Philosophy and Ortodoxy.

2. Periode Perkembangan

Periode ini dimulai sejak kepulangnannya dari Pakistan sampai menjelang keberangkatannya ke Amerika. Pada periode ini pendekatan Fazlur Rahman mulai berpindah dari pendekatan historis de pendekaatan normatif. Maksudnya, memahami Islam sebagai penyelesai problem. Misalnya dalam masalah keluarga, riba dan bunga bank, pendidikan, dll. Berikut karya-karya Fajlur Rahman dalam periode perkembangan:
a. Islamic Methodology in History.
b. Islam.
c. Islamic Stuides (Jurnal).

\footnotetext{
${ }^{8}$ Abd A'la, Dari Neomodernisme ke Islam Liberal, (Jakarta: Paramadina, 2009), hlm. 34-35.

${ }^{9}$ Sutrisno, Fazlur Rabman..., hlm. 65-83.
} 
3. Periode kematangan

Periode ini dimulai sejak kepulangannya dari Amerika hingga wafatnya tahun 1988. Secara epistimlogis Fazlur rahman akhirnya mampu menggabungkan antara pendekatan historis dan normatif menghasilkan metode yang sistematis dan komprehensif. Berikut karya-karya Fazlur Rahman dalam periode kematangan:

a. Philosophy of Mulla Sadra Shirazi.

b. Majir Themes of the Qur'an.

c. Islam and Modernity: Transformation Intellectual Tradition.

d. Health and Medicinne in Islamic Tradition.

\section{Pemikiran Pendidikan Islam Fazlur Rahman}

Fazlur Rahman banyak menulis tentang Pendidikan Islam dengan menggunakan metode kritik sejarah. Motode kritik yang digunakan oleh Fazlur Rahman tidak menekankan pada kronologi berjalannya pendidikan yang ada di dunia Islam. Tetapi, menekankan pada nilai-nilai yang tergantung dalam data-data sejarah pendidikan di dunia Islam. Metode ini diterapkan dalam deskripsi nilai-nilai sejarah pendidikan umat Islam, khususnya yang ada di Turki, Mesir, Iran, Pakistan, dan Indonesia. ${ }^{10}$

Dalam pendidikan Islam, Fazlur Rahman menulis artikel yang berjudul "The alQur'anic Solution of Pakistan's Educational Problem”. Dalam artikel ini dijelaskan cara Fazlur Rahman menerapkan gerakan double movement yang diaplikasikan dalam dunia pendidikan Islam. Metode double movement dapat ditemukian melalui empat langkah, yaitu: ${ }^{11}$

1. Identifikasi terhadap pendidikan umat Islam waktu itu.

2. Menemukan problem pendidikan yang ada.

3. Mencari rujukan pada al-Qur'an dan Hadis.

4. Berusaha memberikan alternatif solusi atas problem tersebut berdasarkan alQur'an dan Hadis.

Setiap kegiatan yang akan dilaksanakan pastilah membutuhkan dasar guna melaksanakan kegiatan tersebut. Landasan dalam suatu kegiatan bertujuan untuk menentukan tujuan yang hendak dicapai. Menurut Fajlur Rahman dalam dunia

${ }^{11}$ Sutrisno, Fazlur Rabman, 151. 
pendidikan landasan yang akan ditanamkan harus berorientasi untuk waktu yang bersifat ganda, yakni dunia dan akhirat. Artinya, selain mempelajari ilmu agama sebagai dasar hidup (way of life) juga mempelajari ilmu pemgetahuan alam. Sumber nilai yang dijadikan dasar pendidikan dalam Islam adalah al-Qur'an, hadis dan ijtihad. $^{12}$

Di dalam al-Qur'an, hadis dan Ijtihad terdapat nilai-nilai fundamental yang dapat dijadikan dasar pendidikan dalam Islam. Nilai-nilai tersebut adalah sebagai berikut:

1. Nilai Tauhid

Tauhid berati pengakuan terhadap ke-esaan Allah SWT, mengandung kesempurnaan kepercayaan kepada Allah meliputi tauhid Rububiyah dan tauhid Ulubiyah. Penanaman tauhid sejak awal pada anak didik bertujuan ketika suatu saat mereka mengalami kesesatan dalam berfikir akan kembali pada landasan dasar yakni al-Qur'an dan Hadis. ${ }^{13}$

2. Nilai Kemanusiaan

Nilai kemanusiaa adalah pengakuan kemuliaan manusia karena memiliki harkat dan martabat. Menjadikan nilai kemanusiaan sebagai dasar pendidikan karena proses pendidikan dalam Islam menjamin potensi kemanusiaan atau fitrah manusia yang dibawa sejak lahir dan dikembangkan secara optimal. Dengan nilai kemanusiaan pendidikan tidak hanya dikembangkan sebatas intelektual, namun juga secara moral. ${ }^{14}$

3. Nilai Kesatuan Umat Manusia

Menggunakan prinsip kesatuan umat sebagai dasar pendidikan dalam Islam maka pendidikan harus dijalankan dengan sistem kerja. Kesatuan umat yang saling bekerja sama merupakan jaminan kelangsungan hidup dalam mencapai kemaslahatan. ${ }^{15}$

12 Gunawan Ikhtiono, Konsep Pendidikan Nondikotomik dalam Perspektif Fąlur Rahman, (Yogyakarta: Kaukaba Dipantara, 2014), hlm. 39-40.

${ }^{13}$ Gunawan Ikhtiono, Konsep Pendidikan, 43.

${ }^{14}$ Gunawan Ikhtiono, Konsep Pendidikan, 43-45

15 Gunawan Ikhtiono, Konsep Pendidikan, 47-48. 
4. Nilai Rahmatan Lil'alamin

Prinsip Rahmatan lil'alamin dalam proses pelaksanaan pendidikan dalam Islam berfungsi secara komprehensip dalam proses penyusunan konsep, teori, dan falsafah pendidikan. ${ }^{16}$

Pendidikan Islam yang diterapkan oleh Fajlur Rahman sesungguhnya memiliki kaitan fungsi dengan ajaran Islam dalam kehidupan baik secara individu maupun masyarakat. Secara individu, pendidikan Islam berupaya menyadarkan manusia berdasarkan fungsi dan kedudukannya sebagai khalifah Allah di muka bumi. Fungsi pendidikan dalam Islam dibagi menjadi tiga bagian, yaitu:

1. Pendidikan sebagai pengembangan potensi

Setiap manusia pastilah memiliki potensi dan kemampuan diri sedangkan tugas pendidikan sebagai suatu proses untuk mengembangkan dan menumbuhkan potensi yang dimiliki. ${ }^{17}$

2. Pendidikan sebagai pewaris budaya

Pendidikan sebagai pewaris budaya merupakan usaha terhadap pewarisan nilai-nilai bagi kehidupan manusia sebagai mana yang telah diungkapkan oleh Fajlur Rahman bahwa tugas pendidikan Islam selanjutnya adalah mewariskan nilai-nilai budaya Islam. ${ }^{18}$ Yang dimaksudkan dengan nilai-nilai budaya Islam adalah hasil cipta, karya, dan karsa umat Islam. Pendidikan adalah pewaris budaya yang layak diwariskan kepada generasi satu ke yang lainnya, contohnya seperti kejuujran, keadilan, dan lainnya.

3. Pendidikan sebagai interaksi antara potensi dan budaya

Fungsi pendidikan sebagai interaksi antara potensi dan budaya merupakan kelanjutan dari fungsi pertama dan fungsi kedua. Pendidikan dapat dikatakan sebagai persimpangan jalan antara perkembangan sosial budaya, termasuk ilmu pengetahuan dan teknologi. Pendidikan mempengaruhi dan dipengaruhi oleh keadaan lingkungan. Pendidikan dapat memberi sekaligus menerima, menghasilkan tetapi juga dihasilkan. Fungsi ini dimaksudkan dengan pendidikan sebagai suatu proses memberi dan menerima antara manusia dan lingkungannya.

\footnotetext{
${ }^{16}$ Gunawan Ikhtiono, Konsep Pendidikan, 48.

${ }^{17}$ Gunawan Ikhtiono, Konsep Pendidikan, 52.

18 Gunawan Ikhtiono, Konsep Pendidikan, 56.
} 
Proses bahwa manusia mengembangan dan menciptakan kemapuan-kemampuan yang diperlukan untuk mengubah kondisi kehidupan, kemanusiaan dan lingkungannya. ${ }^{19}$

Dalam bukunya yang berjudul "Islam and Modernity: Transformation of an Intellectual Tradition”, yang merupakan hasil dari sebuah proyek riset yang dilaksanakan di Universitas Chicago yang telah dibiayai oleh Ford Fondation dalam pendidikan Islam. Fazlur Rahman menegaskan bahwa yang dimaksudkan dengan "Pendidikan Islam" bukanlah berupa perlengkapan dan peralatan-peralatan fisik atau kuasi-fisik pengajaran seperti buku-buku yang diajarkan ataupun struktur eksternal pendidikan, tetapi adalah apa yang disebut sebagai “intelektualisme Islam". Intelektualisme Islam merupakan esensi pendidikan tinggi Islam dan pertumbuhan suatu pemikiran Islam yang asli dan memadai, yang harus memberikan kriteria untuk menilai keberhasilan atau kegagalan sebuah sistem pendidikan Islam. ${ }^{20}$

Berikut adalah berbagai upaya pembaharuan dalam pendidikan Islam yang dilakukan oleh Fazlur Rahman berdasarkan pengalaman, pengamatan dan penelitian yang sebelumnya telah dilakukan:

1. Tujuan Pendidikan Islam

Manusia merupakan inti utama dalam proses pendidikan. Hal ini dapat dipahami dengan mudah dari kenyataan bahwa pendidikan memiliki kepentingan untuk mengarahkan manusia kepada tujuan-tujuan tertentu. Al-Qur-an telah menjelaskan bahwa tujuan Allah menciptakan manusia agar menjadi khalifah di muka bumi. Jelas sudah bahwa keberadaan manusia dalam kehidupan adalah melaksanakan tugas untuk membangun dan mengolah dunia sesuai dengan kehendak Ilahi, sehingga menciptakan tata sosial yang bermoral di atas dunia. ${ }^{21}$

Berkaitan dengan ini, Dr. Muhammad Quraish Shihab menyebutkan bahwa tujuan dalam penciptaan manusia adalah sebagai khalifah di dunia maka semua aktifitas yang dilakukan manusia haruslan berakhir dengan pengabdian kepada Allah. Maka tujuan pendidikan adalah mengantar manusia ke arah tersebut

${ }^{19}$ Gunawan Ikhtiono, Konsep Pendidikan, 61-62.

${ }^{20}$ Fazlur Rahman, Islam and Modernity: Transformation of an Intellectual Tradition, Terj. Ahsin Mohammad, (Bandung: Pustaka, 1995). Hlm, 1.

21 Abu Muhammad Iqbal, Pemikiran Pendidikan Islam: Gagasan-Gagasan Besar Para Ilmuwan Muslim, (Yogyakarta: Pustaka Pelajar, 2015). Hlm, 616. 
dengan upaya mengembangkan potensi-potensi yang dimiliki. Selain itu, tujuan pendidikan Islam dengan mewujudkan pengabdian murni kepada allah dalam kehidupan manusia tingkat individu, masyarakat dan kemanusiaan, serta bangkitnya manusia dengan peranannya beraneka ragam untuk memakmurkan alam sesuai dengan ajaran Islam. ${ }^{22}$

2. Sistem Pendidikan

Fazlur Rahman menunjukkan sebuah contoh pencarian sistem pendidikan yang telah diusahakan oleh Iqbal untuk menemukan sistem pendidikan yang akan menjadi kepribadian manusia tidak saja "berpengetahuan" tetapi juga bersifat kreatif dan dinamis. Iqbal selama ini, menurut Fazlur Rahman mengkritik dua sistem pendidikan. Yaitu: pertama, sistem pendidikan kaum ulama ortodoks dan kaum sufi yang memiliki kecenderungan menjauhkan seseorang dari masyarakat. Kedua, sistem pendidikan modern yang hampir keseluruhan condong kepada lenologi dan materialisme dan bersifat merusak nilai-nilai manusia yang lebih tinggi. ${ }^{23}$

Fazlur Rahman menawarkan solusi dari permasalahan dikotomi sistem pendidikan dengan cara mengintegrasikan antara ilmu agama dengan ilmu-ilmu umum secara organis dan menyeluruh. Sebab pada dasarnya ilmu pengetahuan itu terintregasi dan tidak dapat dipisah-pisahkan. Dalam kurikulum maupun silabus pendidikan Islam harus tercakup ilmu-ilmu umum dn ilmu-ilmu agama. Metode yang ditawarkan oleh Fazlur Rahman pernah diterapkan pada masa keemasan Islam. Pada masa itu ilmu dipelajari secara utuh dan seimbang antara ilmu dunia dan ilmu akhirat. ${ }^{24}$

Metode yang dipergunakan dalam hal belajar-mengajar tidak sebatas pada hafalan saja. Namun, lebih dikembangkan dengan menghafalkan, memahami kemudia menganalisa ilmu yang didapat.

3. Peserta Didik

Bagi Fazlur Rahman, ilmu pengetahuan itu prinsipnya adalah satu yaitu berasal dari Allah SWT. Namun, akibat dikotomi antara ilmu-ilmu agama dan ilmu-ilmu

\footnotetext{
22 Abu Muhammad Iqbal, Pemikiran Pendidikan, 612.

${ }^{23}$ Abu Muhammad Iqbal, Pemikiran Pendidikan, 612-613.

24 Abu Muhammad Iqbal, Pemikiran Pendidikan, 619-620.
} 
umum mengakibatkan kualitas intelektual anak didik dan munculnya pribadipribadi yang pecah (split personality). Hal ini juga berdampak pada lahirnya anak didik yang tidak memiliki komitmen spiritual dan intelektual yang mendalam terhadap Islam yang muncul dari lembaga-lembaga Islam. ${ }^{25}$

Dari permasalahan di atas Fazlur Rahman memiliki dua solusi agar terbentuknya anak didik dengan baik dan benar, yaitu : pertama, anak didik harus diberikan pelajaran mengenai al-Qur'an melalui metode-metode yang memungkinkan al-Qur'an bukan hanya dijadikan sebagai sumber inspirasi tetapi juga dijadikan sebagai rujukan tertinggi untuk menyelesaikan masalah-masalah dalam kehidupan sehari-hari yang semakin komplek dan menantang. Pengajaran Islam yang selama ini bersifat doktriner (hanya untuk menanamkan keimanan) sekarang harus diberikan secara kritis. Hal ini dikarenakan tradisi akan terus berkembang dan sarjana muslim harus mampu mengikuti perkembangan yang terus berlanjut, agar Islam selalu relevan dengan segala permasalahan umat. ${ }^{26}$

Kedua, memberikan materi disiplin ilmu-ilmu Islam secara historis kritis dan holistik. Yang dimaksudkan adalah studi kritis terhadap perkembangan ilmu-ilmu Islam di berbagai bidang seperti hukum, teologi, etika dan filsafat. Fazlur Rahman mampu mengintegrasikan pikiran-pikiran tersebut ke dalam sebuat konsep islam yang utuh dan integratif. ${ }^{27}$

4. Pendidik

Pendidik dalam pendidikan Islam dimaknai sebagai seseorang yang mampu bertanggung jawab terhadap perkembangan anak didik dengan mengupayakan perkembangan seluruh potensi anak didik, baik dalam potensi efektif, kognitif dan psikomotorik. Menurut Fazlur Rahman dalam kenyataannya amat sulit mendapatkan pendidik yang berkualitas. Maka dari itu Fazlur Rahman menawarkan lima gagasannya yang berkaitan dengan pembentukan tenaga didik yang berkualitas, ${ }^{28}$ adalah sebagai berikut:

a. Merekrut dan mempersiapkan anak didik yang memiliki bakat terbaik dan mempunyai komitmen yang tinggi terhadap lapanga agama Islam. Anak didik

\footnotetext{
25 Abu Muhammad Iqbal, Pemikiran Pendidikan, 620-621.

26 Abu Muhammad Iqbal, Pemikiran Pendidikan, 621.

${ }^{27}$ Abu Muhammad Iqbal, Pemikiran Pendidikan, 621.

28 Abu Muhammad Iqbal, Pemikiran Pendidikan, 622.
} 
seperti ini harus dibina dan diberikan insentif yang memadai untuk membantu memenuhi keperluannya dalam peningkatan karir intelektual mereka.

b. Mengangkat lulusan madrasah yang relatif cerdas atau menunjuk sarjanasarjana modern yang telah menerima gelar doktor serta telah berada di lembaga-lembaga keilmuan tinggi sebagai guru besar.

c. Para pendidik harus dilatih di pusat-pusat studi keislaman di luar negeri khususnya di Barat.

d. Mengangkat beberapa lulusan madrasah yang memiliki pengetahuan bahasa Inggris dan mencoba melatih mereka ke dalam teknik riset modern dan sebaliknya menarik lulusan universitas bidang filsafat dan ilmu sosial serta memberikan mereka bekal ilmu disiplin islam klasik

e. Menggiatkan para pendidik untuk melahirkan karya-karya keislaman secara kreatif dan memiliki tujuan. ${ }^{29}$

5. Sarana Pendidikan

Sarana pendidikan berupa gedung, perpustakaan serta lainnya memiliki hubungan yang amat erat dengan mutu sekolah. Sekalipun sederhana, hal tersebut juga amat berpengaruh terhadap mutu pendidikan. Dari pengamatan Fazlur Rahaman dari bebeapa negara Islam yang dikunjunginya menunjukkan perpustakaan di lembaga pendidikan masih belum memadai, dilihat dari jumlah buku-buku di dalamnya terutama jumlah buku yang menggunakan bahasa arab dan bahasa inggris. Untuk mengatasi masalah tersebut Fazlur Rahman mengusulkan agar fasilitas perpustakaan harus dilengkapi denga buku-buku yang menggunakan bahasa Arab dan bahasa Inggris. ${ }^{30}$ Karena, Fazlur Rahman berharap kepada para cendekiawan muda agar mampu menguasai bahasa, dikarenakan menguasai bahasa sama dengan mampu mengusai budaya.

${ }^{29}$ Abu Muhammad Iqbal, Pemikiran Pendidikan, 622-623.

30 Abu Muhammad Iqbal, Pemikiran Pendidikan, 624-625. 


\section{Pendidikan Islam di Indonesia}

Pendidikan Islam di Indonesia mengalami kemamajuan semenjak zaman reformasi. Dimana, zaman reformasi adalah saat dimana Indonesia mengatur dan menertibkan kembali sesuatu yang kacau balau. Yang didalamnya terdapat kegiatan menambah, mengganti, mengurangi dan memperbaharui. ${ }^{31}$ Sehingga terbitlah kebijakan-kebijakan pemerintah era Reformasi yang ditujukan pada upaya untuk mengatasi masalah yang ditimbulkan pada masa Orde Baru. Salah satu kebijakan yang menguntungkan bagi dunia pendidikan adalah, dengan memberikan peluang yang lebih luas kepada masyarakat untuk mengekspresikan kebebasannya, atau yang lebih dikenal dengan menumbuhkan praktik demokrasi dalam politik, ekonomi, pendidikan, dan hukum. ${ }^{32}$

Sejalan kebijakan yang diterbitkan menimbulkan keadaan pendidikan Islam yang secara umum keadaannya jauh lebih baik. Keadaan pendidikan tersebuat dapat dikemukakan sebagai berikut:

1. Kebijakan tentang pemantapan pendidikan Islam sebagai bagian dari sistem pendidikan nasional. Upaya ini dilakukan melalui penyempurnaan Undang-Unang Nomor 2 Tahun 1989 menjadi Undang-Undang Nomor 20 Tahun 2003 tentang Sistem Pendidikan Nasional. Apabila pada Undang-Undang tahun 1989 , hanya menyebutkan madrasah yang masuk ke dalam sistem pendidikan nasional, maka pada Undang-Undang tahun 2003 yang masuk ke dalam sistem pendidikan nasional meliputi pesantren, ma'had Ali, Raudhatul Athfal, dan majelis taklim. Dengan masuknya ke dalam sistem pendidikan nasional, maka eksistensi dan fungsi pendidikan Islam semakin diakui, juga menghilangkan kesan diskriminasi dan dikotomi. ${ }^{33}$

2. Kebijakan tentang peningkatan anggaran pendidikan Islam. Kebijakan ini misalnya terlihat pada diterapkannya anggaran pendidikan sebanyak $20 \%$ dari Anggaran Pendapatan dan Belanja Negara (APBN). ${ }^{34}$

\footnotetext{
${ }^{31}$ Abdullah Nata, Sejarah Pendidikan Islam, (Jakarta: Kencana, 2011), 347.

32 Abdullah Nata, Sejarah Pendidikan, 348.

33 Abdullah Nata, Sejarah Pendidikan, 352.

${ }^{34}$ Abdullah Nata, Sejarah Pendidikan, 353.
} 
3. Program wajib belajar 9 tahun, yakni bagi setiap anak Indonesia wajib memiliki pendidikan minimal sampai denan tamat sekolah lanjutan pertama, yakni SMP atau Tsanawiyah. ${ }^{35}$

4. Penyelenggaraan sekolah bertarat Nasional (SBN), internasional (SBI), yaitu yang seluruh komponen pendidikannya menggunakan standar nasional dan internasional. Sekolah yang bertaraf nasional dan internasional tidak hanya yang bernaung dibawah Kementrian Pendidikan Nasional, melainkan juga pada sekolah yang bernaung di bawah Kementrian Agama. ${ }^{36}$

5. Kebijakan sertifikasi guru dan dosen bagi semua guru dan dosen baik negri atau swasta, baik guru umum maupun guru agama, baik guru yang berada dibawah naungan Kementrian Pendidikan Nasional maupun Kementrian Agama. Program ini terkait erat dengan program peningkatan mutu yang bertolak dari peningkatan mutu tenaga guru dan dosen sebagai tenaga profesional. Melalui program sertifikasi tersebut kompetensi akademik, kompetensi pedagogik (teaching skill), kompetensi kepribadian dan kompetensi sosial guru dan dosen ditingkatkan. ${ }^{37}$

6. Pengembangan kurikulum berbasis kompetensi (KBK/tahun 2004) dan Kurikulum Tingkat Satuan Pendidikan (KTSP/tahun 2006). ${ }^{38}$

7. Pengembangan pendekatan pembelajaran yang tidak hanya berpusat pada guru (teacher centris) melalui kegiatan teaching, melainkan juga berpusat pada murid (student centris) melalui kegiatan belajar (belajar) dalam suasana partispatif, inovatif, aktif, kreatif, efektif, dan menyenangkan. ${ }^{39} \mathrm{Hal}$ ini merupakan salah satu scientific approach dalam pembelajaran K-13.

8. Penerapan manajemen yang berorientasi pada pemberian pelayanan yang baik dan memuaskan sebagaimana yang terdapat dalam konsep TQM (Total Quallity Management). ${ }^{40}$

9. Kebijakan mengubah nomenklatur dan sifat madrasah menjadi sekolah umum yang memiliki ciri khas keagamaan. Sehingga siswa selain memperoleh

\footnotetext{
35 Abdullah Nata, Sejarah Pendidikan, 354.

${ }^{36}$ Abdullah Nata, Sejarah Pendidikan 354-355.

37 Abdullah Nata, Sejarah Pendidikan, 355-356.

38 Abdullah Nata, Sejarah Pendidikan, 356-357.

39 Abdullah Nata, Sejarah Pendidikan, 357.

40 Abdullah Nata, Sejarah Pendidikan, 358.
} 
pendidikan yang terdapat pada sekolah umum, juga mendapatkan pendidikan agama. $^{41}$

\section{Relevansi Pemikiran Fazlur Rahman terhadap Pendidikan di Era Modern}

Antara pendidikan Islam dan pendidikan nasional Indonesia tidak dapat dilepaskan antara satu dengan yang lainnya. Hal ini dapat dilihat dari dua segi: pertama, dari konsep penyusunan sistem pendidikan nasional Indonesia itu sendiri. Kedua, hakikat pendidikan Islam dalam kehidupan beragama kaum muslimin di Indonesia.penyusunan suatu sistem pendidikan nasional harus mementingkan masalah-masalah eksistensi umat manusia pada umumnya dan eksistensi bangsa Indonesia pada khususnya dalam hubungannya dengan masa lampau, masa kini, dan kemungkinan-kemungkinan perkembangan masa depan. ${ }^{42}$

Setelah membahas mengenai konsep pendidikan yang diajukan oleh Fazlur Rahman sebagaimana sesuai dengan pengalaman, pengamatan dan penelitian yang dilakuakan berserta perkembangan pendidikan yang terjadi di Indonesia, maka penulis menyimpulkan terdapat beberapa relevansi antara pemikiran pendidikan Fazlur Rahman dan Pendidikan di Indonesia. Diantaranya adalah sebagai berikut:

1. Sistem Pendidikan

Terdapat relevansi antara sistem pendidikan yang diajukan oleh Fazlur Rahman, yaitu solusi dari permasalahan dikotomi sistem pendidikan dengan cara mengintegrasikan antara ilmu agama dengan ilmu-ilmu umum secara organis dan menyeluruh. Dengan sistem pendidikan yang diterapkan di Indonesia, yaitu dengan mengadakan pelajaran agama dalam setiap jenjang pendidikan. Atau dapat kita lihat dalam sistem pembelajaran yang diterapkan dalam Pondok Pesantrean yang tersebar di seluruh Indoesia, yang menyeimbangkan antara pelajaran umum dan pelajaran agama.

2. Pendidik

Pendidik dalam pendidikan Islam dimaknai sebagai seseorang yang mampu bertanggung jawab terhadap perkembangan anak didik dengan mengupayakan perkembangan seluruh potensi anak didik, baik dalam potensi efektif, kognitif

${ }^{41}$ Abdullah Nata, Sejarah Pendidikan, 359.

42ZZuhairini, Sejarah Pendidikan Islam, (Jakarta: Bumi Aksara, 1997), 231-232. 
dan psikomotorik. Maka Fazlur Rahman menawarkan lima gagasannya yang berkaitan dengan pembentukan tenaga didik yang berkualitas, yang akhirnya akan membentuk pendidikk yang berkualitas.

Dan relevansinya dengan pendidikan di Indonesia yaitu diadakannya serfikasi guru dan dosen. Program ini terkait erat dengan program peningkatan mutu yang bertolak dari peningkatan mutu tenaga guru dan dosen sebagai tenaga profesional. Melalui program sertifikasi tersebut kompetensi akademik, kompetensi pedagogik (teaching skill), kompetensi kepribadian dan kompetensi sosial guru dan dosen ditingkatkan. Sehingga lahirnya guru-guru dan dosen yang berkualitas dan profesional.

3. Sarana Pendidikan

Sarana pendidikan berupa gedung, perpustakaan serta lainnya memiliki hubungan yang amat erat dengan mutu sekolah. Sekalipun sederhana, hal tersebut juga amat berpengaruh terhadap mutu pendidikan. Fazlur Rahman mengusulkan agar fasilitas perpustakaan harus dilengkapi denga buku-buku yang menggunakan bahasa Arab dan bahasa Inggris.

Hal di atas sejalan dengan pekembangan pendidikan yang ada di Indonesia dimana sesuatu dengan Peraturan Pemerintah Nomor 19 Tahun 2005 tentang Standar nasional Pendidikan Nasional (SNP) yang meliputi: ${ }^{43}$

1) Standar isi (Kurikulum)

2) Standar mutu lulusan

3) Standar proses pembelajaran

4) Standar pendidik dan tenaga kependidikan

5) Standar sarana dan prasarana

6) Sandar pembiayaan

7) Standar penilaian

Selain itu pengadaan sekolah bertaraf Internasional mewajibkan pemerintah dan sekolah untuk melengkapi dan menambah buku-buku yang menggunakan bahasa arab dan inggris guna menunjang keberlangsungan kegiatan belajar mengajar.

${ }^{43}$ Abuddin Nata, Sejarah Pendidikan, 358-359. 


\section{KESIMPULAN}

Fazlur Rahman lahir di daerah Hazara daerah Barat Laut Pakistan pada tanggal 21 September 1919 bertepatan dengan tahun 1338 H. Fazlur Rahman mampu menghafal al-Qur'an pada usia 10 tahun berkat didikan dari sang ayah. Pada tahun 1933 Fajlur Rahman melanjutkan studinya ke Lahore dan memasuki sekolah modern. Pada tahun 1940 Fajlur Rahman menyelesaikan B.A.-nya dalam bidang bahasa Arab di Universitas Punjab. Pada tahun 1942 Fajlur Rahman telah menyelesaikan Masternya dalam bidang bahasa Arab di Universitas Punjab. Pada tahun 1946 Fajlur Rahman berangkat ke Inggris melanjutkan studinya di Oxford dan menyelesaikan program Ph.D.-nya pada tahun 1949.

Perkembangan pemikiran Fajlur Rahman dapat dilihat dari banyak karya yang telah diterbitkan. Perkembangan pemikiran Fajlur Rahman dapat diklasifikasikan kedalam tiga periode, yaitu:Periode Pembentukan, Periode Perkembangan, dan Periode kematangan.

Dalam pendidikan Islam, Fajlur Rahman menulis artikel yang berjudul "The alQur'anic Solution of Pakistan's Educational Problem". Dalam artikel ini dijelaskan cara Fazlur Rahman menerapkan gerakan double movement yang diaplikasikan dalam dunia pendidikan Islam. Menurut Fazlur Rahman dalam dunia pendidikan landasan yang akan ditanamkan harus berorientasi untuk waktu yang bersifat ganda, yakni dunia dan akhirat.

Berikut adalah berbagai upaya pembaharuan dalam pendidikan Islam yang dilakukan oleh Fazlur Rahman berdasarkan pengalaman, pengamatan dan penelitian yang sebelumnya telah dilakukan:

1. Tujuan Pendidikan Islam

Keberadaan manusia dalam kehidupan adalah melaksanakan tugas untuk membangun dan mengolah dunia sesuai dengan kehendak Ilahi, sehingga menciptakan tata sosial yang bermoral di atas dunia, dan hal ini mampu diwujudkan dengan pendidikan yanng berkualitas.

2. Sistem Pendidikan

Fazlur Rahman menawarkan solusi dari permasalahan dikotomi sistem pendidikan dengan cara mengintegrasikan antara ilmu agama dengan ilmu-ilmu umum secara organis dan menyeluruh. 
3. Peserta Didik

Anak didik harus diberikan pelajaran mengenai al-Qur'an melalui metodemetode yang memungkinkan al-Qur'an bukan hanya dijadikan sebagai sumber inspirasi tetapi juga dijadikan sebagai rujukan tertinggi untuk menyelesaikan masalah-masalah dalam kehidupan sehari-hari yang semakin komplek dan menantang. Dan memberikan materi disiplin ilmu-ilmu Islam secara historis kritis dan holistik.

4. Pendidik

Pendidik dalam pendidikan Islam dimaknai sebagai seseorang yang mampu bertanggung jawab terhadap perkembangan anak didik dengan mengupayakan perkembangan seluruh potensi anak didik, baik dalam potensi efektif, kognitif dan psikomotorik, maka harus diwujudkannya tenaga didik yang berkualitas.

5. Sarana Pendidikan

Sarana pendidikan berupa gedung, perpustakaan serta lainnya memiliki hubungan yang amat erat dengan mutu sekolah. Fazlur Rahman mengusulkan agar fasilitas perpustakaan harus dilengkapi denga buku-buku yang menggunakan bahasa Arab dan bahasa Inggris.

Pendidikan khususnya pendidikan Islam mengalami kemajuan setelah era Reformasi dengan diterditkannya kebijakan tentang pemantapan pendidikan Islam sebagai bagian dari sistem pendidikan nasional. Upaya ini dilakukan melalui penyempurnaan Undang-Undang Nomor 2 Tahun 1989 menjadi Undang-Undang Nomor 20 Tahun 2003 tentang Sistem Pendidikan Nasional. Apabila pada UndangUndang tahun 1989 , hanya menyebutkan madrasah yang masuk ke dalam sistem pendidikan nasional, maka pada Undang-Undang tahun 2003 yang masuk ke dalam sistem pendidikan nasional meliputi pesantren, ma'had Ali, Raudhatul Athfal, dan majelis taklim. Dengan masuknya ke dalam sistem pendidikan nasional, maka eksistensi dan fungsi pendidikan Islam semakin diakui, juga menghilangkan kesan diskriminasi dan dikotomi.

Terdapat beberapa relevansi antara pemikiran pendidikan Fazlur Rahman dan Pendidikan di Indonesia. Diantaranya sistem pendidikan, mutu pendidik, sarana dan pendidikan. 


\section{DAFTAR PUSTAKA}

A'la,Abd, 2009,Dari Neomodernisme ke Islam Liberal, Jakarta: Paramadina.

Amal,Taufik Adnan, 1994, Islam dan Tantangan Modernitas: Studi atas Pemikiran Hukum Fą̧lur Rahman, Bandung: Mizan.

Ikhtiono,Gunawan, 2014,Konsep Pendidikan Nondikotomik dalam Perspektif Fąlur Rabman, Yogyakarta: Kaukaba Dipantara.

Iqbal,Abu Muhammad, 2015,Pemikiran Pendidikan Islam: Gagasan-Gagasan Besar Para Ilmuwan Muslim, Yogyakarta: Pustaka Pelajar.

Mahmud, Metode Penelitian Pendidikan. CV. Pustaka Setia. Bandung, 2011.

Maragustam, 2018, Filsafat pendidikan Islam Menuju Pembentukan Karakter, Yogyakarta : Pascasarjana UIN Sunan Kalijaga.

Nata,Abuddin, 2011, Sejarah Pendidikan Islam, Jakarta: Kencana.

Rahman,Fazlur, 1995,Islam and Modernity: Transformation of an Intellectual Tradition, Terj. Ahsin Mohammad, Bandung: Pustaka.

Saifuddin Anwar. Metode Penelitian, Pustaka Pelajar Ofset, Yogyakarta, cet III, 2001)

Sukandrrumidi, 2012, Metodologi Penelitian: Petunjuk Praktis untuk Peneliti Pemula, Yogyakarta: GADJAH MADA UNIVERSITY PRESS.

Sutrisno, 2006, Fålur Rahman: Kajian Terbadap Metode, Epistimologi, dan Sistem Pendidikan, Yogyakarta: Pustaka Pelajar.

Zuhairini, 1997, Sejarab Pendidikan Islam, Jakarta: Bumi Aksara. 